\title{
Eradication of Fatal Textile Industrial Dyes by Wastewater Treatment
}

\author{
Rohit Kumar Verma ${ }^{1(\mathbb{D})}$, Mahipal Singh Sankhla ${ }^{2, *(\mathbb{D}}$, Nikhil V. Rathod ${ }^{3(\mathbb{D}}$, Swaroop S. Sonone ${ }^{3(\mathbb{D}}$, \\ Kapil Parihar 4 (D), Gaurav Kumar Singh 5 (D)
}

1 Dr. A P J Abdul Kalam Institute of Forensic Science \& Criminology, Bundelkhand, University, Jhansi, U.P., India; rohitlyn8423@gmail.com (R.K.V.);

2 Department of Forensic Science, Institute of Sciences, SAGE University, Indore, M.P., India; mahipal4n6@gmail.com (M.S.S.);

3 Government Institute of Forensic Science, Aurangabad, Maharashtra, India; nikhilrathod800@gmail.com (N.V.R.); sononeswap4@gmail.com (S.S.S.);

4 Department of Forensic Science, Vivekanand Global University, Jaipur, Rajasthan, India; kparihar94@ gmail.com (K.P.);

5 Department of Forensic Science, University Institute of Applied Health Science, Chandigarh, Gharun, Mohali, Punjab, India; grvsngh01@gmail.com (G.K.S.);

* Correspondence: mahipal4n6@gmail.com (M.S.S.);

Scopus Author ID 57219964786

Received: 3.03.2021; Revised: 4.04.2021; Accepted: 7.04.2021; Published: 20.04.2021

\begin{abstract}
Dyes are typically existing in trace masses in the preserved wastes of numerous manufactures. The adsorption efficiency for dye elimination from unwanted water bodies has made it a perfect substitute to further exclusive usage procedures. The emission holding the poisonous cationic dyes from the textile industries is an intimidating issue today due to ecological ratifications and their opposing effect on human biology. Dyes removes from the industrial wastewater overflows effectually detached by consuming adsorbent, such as stimulated carbon, though its price limits large-measure submissions. The removal of dyes from the water is very important in demand to diminish the toxic effects on nature.
\end{abstract}

Keywords: dyes; textiles; industrial wastes; ecology; wastewater; cloth.

(c) 2021 by the authors. This article is an open-access article distributed under the terms and conditions of the Creative Commons Attribution (CC BY) license (https://creativecommons.org/licenses/by/4.0/).

\section{Introduction}

Dyes are the most important industrial contaminants and water pollutants [1]. Numerous industries discharge dyes into effluent, thus fouling the water supply. Relevant companies are fabric industries, dye producing industries, tanneries, paper, and pulp mills, distilleries, electroplating factories, food businesses, etc. [2]. The textile industrial corporation's entire dye utilization is more than 10,000 tons/year, with an estimated $90 \%$ in the fabrics industry worldwide. It is described that around 100 tons of dyes are released into unwanted rivulet by the fabric industry per year [3]. Dye manufacturers and users are focused on the steadiness and celerity of dyes and, subsequently, manufactures dyes that are hard to eradicate from wastewater after usage. The elimination of color from wastewater can be achieved by chemical coagulation, flotation, adsorption, and chemical oxidation $[4,5]$. Adsorption grip promise in dealing with effluent as it is purely planned, convenient, and give sludge-free clean-up operation. AC (granular or powdered) is the utmost broadly utilized adsorbent because it has admirable adsorption productivity for carbon-based compounds. But economically handy $\mathrm{AC}$ is costly. Furthermore, renewal using solutions manufactured by 
minor supplementary effluents, while renewal by rebellious procedure gives rise to $10-15 \%$ loss of adsorbents and its absorption range [6]. Different construction stages occur using these procedures, like textile fabrication, wool formation, cloth formation, and moist processing. Artificial dyes cause widespread health threats when they counter with additional chemical compounds and produce non-degradable secondary products. Scholars have described the occurrence of sulfur, soaps, nitrates, enzymes, vat dyes, naphthol, acetic acid, nitrates, chromium compounds, and heavy metals like lead, nickel, arsenic, copper, cadmium, mercury, cobalt, and fixed secondary elements to give rise to lethal effects [7]. Organic constituents like formaldehyde-based dye fixing agents, hydrocarbon-based softeners, non-biodegradable dyeing chemicals, chlorinated stain removers are cancer-causing. The sewage discharge from textile dyeing industries is poisonous, carcinogenic, mutagenic, and teratogenic chemical components [8]. Hence, decolorization of dyes is a significant feature of effluent treatment before release. It is tough to eliminate the sewage dyes since dyes are not efficiently biodegradable and not eliminated from drain water by conventional drain water systems [9]. Usually, organic aerobic wastewater methodology is not effective for the decolorization of popular dyes. Thus, for the purposed of accomplishing the estimated degree of treatment, it is needed to mix physical, chemical, and biological procedures as ultra-filtration, photooxidation, electrochemical adsorption, and coagulation [10]. Numerous employees have also tried water treatment of dyes by adsorption over economic resources [11-17]. Separately each system has its specific rewards and drawbacks. For example, in separation, low-molecularweight dyes can go through the filter system, and the usage of charcoal precisely has high waste disposal cost and is easy to use. Though, the removal of poisonous slush has a serious disadvantage in exceeding procedures. The ozone treatment is expensive. Progressive oxidation procedures based on photocatalytic deprivation presently exist for the active oxidation of various organic compounds and colorants [18, 19]. The capability of the photocatalytic procedure to entirely damage organic compounds into $\mathrm{CO}_{2}$ and water, devoid of producing some detrimental by-products, has built up its role as a wastewater sterilizer. The methodology has been broadly working for the photo-mineralization of a great numeral of colorants like azo dyes, acid and direct dyes, reactive black \& methylene blue [20]. Numerous biological, chemical, and physical methods such as photolysis, adsorption, electrochemical precipitation, chemical oxidation and reduction, chemical precipitation have been used for the exclusion of dyes from wastewater [21-23]. However, these methodologies are generally not effective in dye elimination or are costly and less adjustable to wide-ranging dye-containing wastewaters [21, 24, 25]. dye is one of the most significant water quality parameters. Throughout the dying method, about 5 - 20\% of the dye are vanished due to its incomplete adsorption on the fibers [26]. Dyes are mass-produced to have high chemical resistance because they are usually chemical species that are very hard to damage (aromatic dyes). Moreover, dye solutions generally contain antifungal agents and antibacterial, which are used to give the fibers more resistance to biological deprivation [27]. Even at moderately low concentrations, the intense color related to the dye affects the transparency of water and aesthetics, thus interfering in photosynthesis and the solubilization of smokes in rivers, lakes, and other surface water bodies. It harms both the water fauna and flora. Also, colored effluents may carry significant quantities of toxic compounds, particularly azo dyes, that are known to be vastly carcinogenic $[28,29]$. Among the several manufacturing sectors in India, the textile and garments industries are one of the oldest, and in the Indian economy, these industries play a significant role. It is an important supplier to much national financial prudence, including small and large-scale 
procedures worldwide. the textile industry is the topmost manufacturing industry globally in terms of its results, employment, and gross domestic production. The textile industry is the main foreign exchange earner after agriculture. Textile industry major proprietor with an overall workforce of $35 \mathrm{mn}$. The textile industry enclosed a diverse variety of events, which contain the manufacture of natural crude resources like spun yarn, jute, wool, cotton \& silk, and artificial fiber. additionally, a wide variety of finished products are made. For textile fibers and yarns, India accounts for about $14 \%$ of the world's production. This contains jute, of which it is the topmost manufacturer. India is the subsequent major manufacturer of fiber, cellulose, yarn, and silk fiber and the fifth main manufacturer of synthetic yarn and fiber [30]. the main impurities present in the wastewater are acids and bases, organic and inorganic solid materials, coloring agents. lignin and tannin are the dyeing agents which give shade to the fabric. Coloring principally contains the usage of colorants under suitable environments to yield stained fabrics. on the other hand, lithography contains the usage of colorants to a limited part of the fabric that is nominated for applying the abstract of the proposal. Last procedures include waterproofing, softening, and cross-linking, but all these stages lead to water pollution. With these operations, diverse manufacturing stages are present, like fabric and yarn formation, wet manufacturing, and textile production. Artificial dyes cause rampant health hazards when they counter with some other chemical compounds and form non-biodegradable secondary products. Scholars have described the occurrence of chromium compounds, sulfur, enzymes, naphthol, soaps, vat dyes, acetic acid, nitrates, and heavy metals like cobalt, nickel, copper, lead, cadmium, arsenic, mercury, and firm auxiliary chemicals to produce lethal impacts. Organic materials like formaldehyde-based dye fixing agents, chlorinated dye removers, hydrocarbon-based softeners, non-biodegradable dying chemicals are cancer-causing. Effluents discharged from fabric dying industries are lethal are teratogenic mutagenic and consist of cancer-causing chemicals [31-35].

\section{Hazards Dye waste of Water Pollution}

Large amounts of water are used in the textile industry during procedures; hence, it is one of the major industrial liquid waste producers (ILW) [36]. The ILW formed by the textile industry is categorized by a high content of impurities such as heavy metals, colorants, and organic and inorganic material [37]. Therefore, it is essential to find a suitable method for ILW that permits the reuse of treated water as this would allow decreasing water utilization in the textile industry. In the treated effluents of many industries, colorants are occurring in small quantities. The efficiency of adsorption for eliminating dye from wastewaters has made it a supreme substitute to some other costly treatment methodologies. The research explores the significant usage of coconut husk $(\mathrm{CH})$ for eliminating Quinoline Yellow dye from effluent, and its proficiency in colorant sorption was linked with activated carbon (AC). Group adsorption research was carried out due to primary dye concentration, adsorption dose, $\mathrm{pH}$, particle size, temperature, and contact time. The adsorption of quinoline yellow onto both the adsorbents, $\mathrm{CH} \& \mathrm{AC}$, was initiate to progress with finer mesh size and increase in adsorbent dosage. Maximal adsorption was detected at lower $\mathrm{pH} 2.5 \mathrm{in} \mathrm{pH}$ values ranging from 2.5 to 9.1 for both the adsorbents. It was detected that with increasing temperature, the rate of adsorption increases for $\mathrm{AC}$, and the method is endothermic, while in the case of $\mathrm{CH}$, with increasing temperature rate of adsorption decreases with indicating that the method is exothermic [38]. Pollution of the water sources is triggered by releases from manufacturing processes which has become a troublesome spectacle because of its effect on ecological wellness and care. Fabric 
trades subsidize hugely to surface river damaging and are classified amongst the prime contaminating of all manufacturing areas [39]. Runoffs from cloth productions are multifaceted combinations of elements differing in quality and quantity. These companies can produce organic \& inorganic wastages combined with effluents from the manufacturing procedures that result in changes in both chemical and biological limits of the receiving water sources [40].

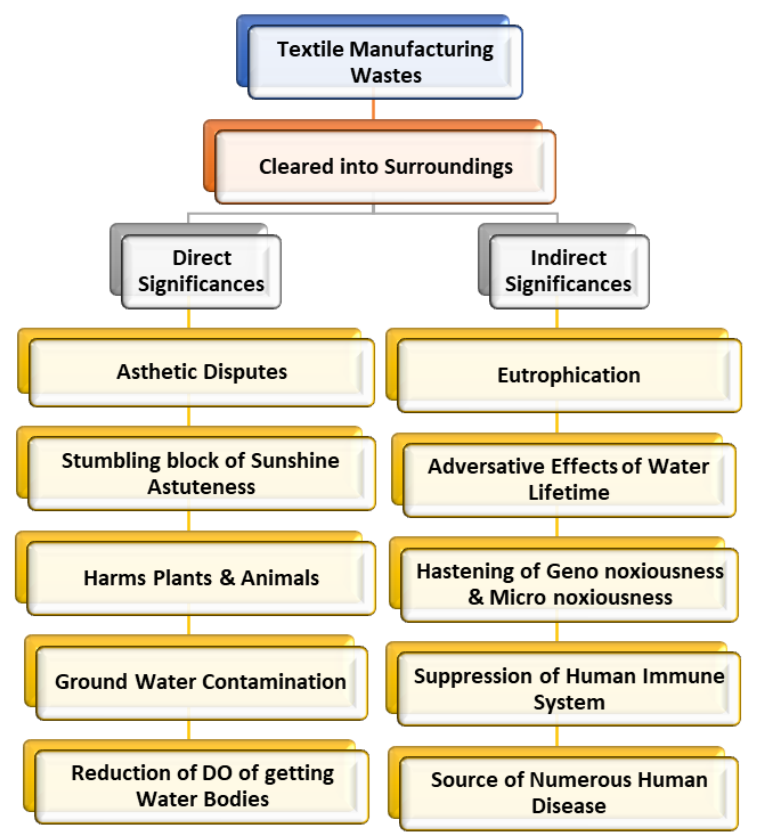

Figure 1. Graphical representation of impacts of fabric wastages released in the environment.

Fabric effluents produced from distinct phases of fabric procedure encompass many contaminants that are destructive to the ecosystem if free the pollutants without a suitable method [30]. The amount of ecological effluence due to dye by water which is used for the bath, is very high $[41,42]$. Ecological contamination triggered by the proclamation of many azo dyes through industrial effluent is an important issue to current daytime [43]. There are great records of chemical and mechanical methods used in the fabric business, and individual procedures have a distinct effect on the ecosystem. The occurrence of dyes, nitrates, sulfur, acetic acid, soaps, naphthol, vat dyes, heavy metallic elements like nickel, cadmium, copper, mercury, cobalt, arsenic, and lead, certain auxiliary chemicals, and chromium compounds all together makes the sewage extremely poisonous. The factory seepage is also frequently of a high $\mathrm{pH}$ and temperature, both of which are tremendously detrimental [44]. Likewise, dye collection hampers sunlight perforation, a disorder in the collecting water environment $[45,46]$. The ecological contamination begun by fabric wastewater sewage shows a worldwide risk to community wellness, and it brings out innovative creativities for conservational renovation for both ecological and economic causes. The Ministry of Environment and Forests, Government of India, has placed the textile industry in the utmost contaminating industries [47]. Pigments and dyes are one of the biggest water contaminants and, if not released appropriately, give rise to environmental disruption. Considering this, the recent study examines the use of thermal power plant by-products, i.e., fly ash, to remove a harmful methylene blue dye from its artificial aqueous solution. Experimentations were showed in the group method to examined the outcome of adsorbent dose, contact time, $\mathrm{pH}$, and temperature. Maximum dye elimination (94.3\%) was completed at $\mathrm{pH} 10$ using an adsorbent dose of $10 \mathrm{~g} / \mathrm{L}$ in $90 \mathrm{~min}$ of contact time at $40^{\circ} \mathrm{C}$. The economic process at neutral $\mathrm{pH}$ and atmospheric temperature $\left(30^{\circ} \mathrm{C}\right)$ gives $89.3 \%$ 
dye elimination taking the same contact time and adsorbent dose [48]. Several dyes are lethal to mammalian life and fishes; they hinder microbes' development and affect fauna and flora. Additionally, numerous dyes and their disintegration imitative have shown poisonous to the marine creature (mammals, microorganisms, aquatic plants, and fish) [49, 50]. They are also cancer-causing in nature and give rise to cerebral abnormalities and intestinal cancer in the embryo. Textile dyes can give rise to allergies such as respiratory diseases and contact dermatitis, eye irritation, allergic reaction in the skin irritation, and irritation to the respiratory tract and mucous membrane. Reactive dyes form covalent bonds with polyamide (PA), woolen fibers, and cellulose. Likewise, it is presumed that reactive dyes can form a bond with $-\mathrm{SH}$ and $-\mathrm{NH}_{2}$ groups of proteins in living creatures [51].

\section{Major Chemicals and Dye used in Synthetic Textile Industry}

The dyes used commonly are divided into natural and synthetic types. Synthetic dyes are easy to produce and provide fastness. Such features of synthetic dyes make them be used more widely than natural dyes. Synthetic dyes are used each and every day worldwide to print the fabrics, leather coloring, hair complexion, etc. Dyes acquire diverse chromophoric groups and among them mostly used are azo, anthraquinone, triarylmethane, etc. The huge amount of dye consumption releases pollutants and produces environmental pollution through the effluents getting discharged from the textile industries or others [52]. Synthetic dyes can be further classified into different types such as the azo dyes, anthraquinone, triarylmethane, Sulphur, and phthalocyanine based on their chemical structure. On the other hand, depending upon their synthetic dyes, a mode can be direct, reactive, disperse basic, and vat type of dying $[53,54]$. The types of dyes used in the synthetic textile industries vary depending upon the type of fabrics manufactured. Depending upon the type of fabrics manufactured, the dyes can be classified into the following different types-

1. Dyes for cellulose fibers

2. Dyes for protein fibers

3. Dyes for synthetic fibers

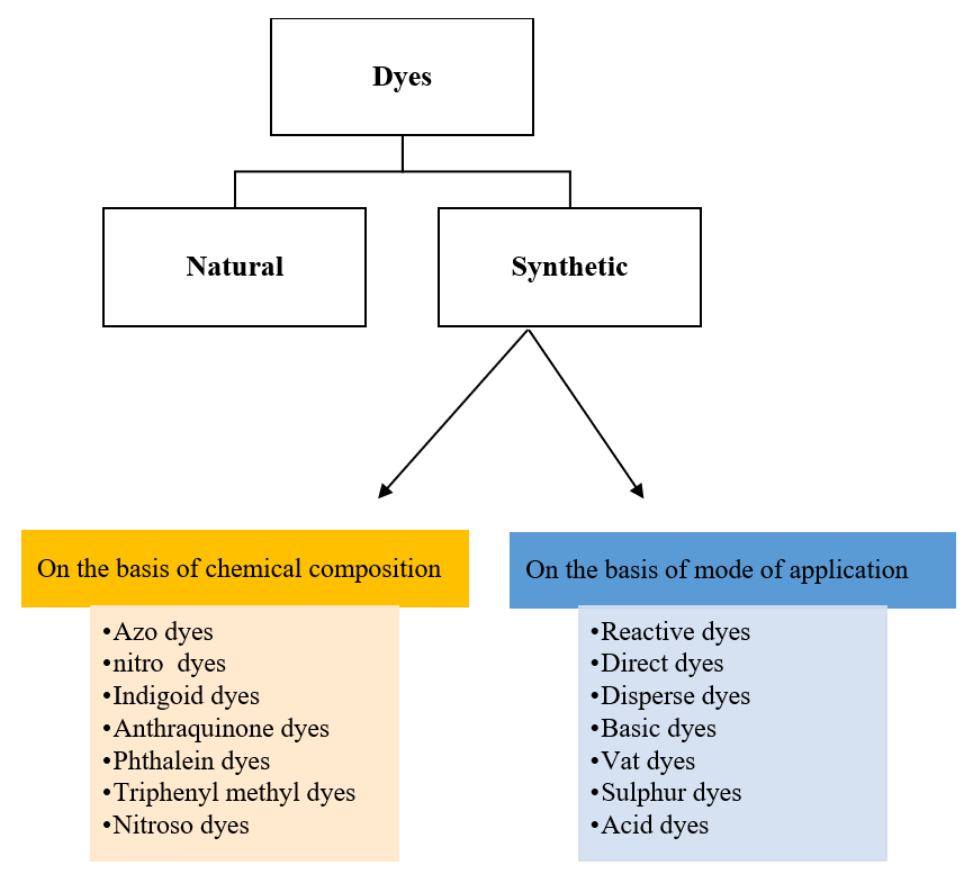

Figure 2. Representation of the classification of dyes. 


\subsection{Dyes for cellulose fibers.}

The reactive dyes are mainly used for the cellulose fibers, while the others used may include indigo, direct, vat, sulfur dyes etc.

\subsubsection{Reactive dyes.}

Such dyes are often referred to as reactive fiber dyes. These dyes are the significant type of dyes used to dye the cellulose fibers and sometimes also dye the protein fibers like silk and wool. These dyes react with the fiber molecules and form covalent bonds with them, which are very effective. According to a study, the productions of reactive dyes in the world have been increased three-fold in the three years (1988 to 2011).

\subsubsection{Procion MX.}

This dye is used at normal room temperature and is found as a kind of cold reactive dye. These dyes are considered to give color inside of fabrics rather than superficially. And these dyes are most commonly used in tie-dyeing and, apart from cellulose fibers, also used for the dyeing of wool, wood paper, basketry stuff, and silk.

\subsubsection{Cibcron F.}

These dyes give an effortless wash fastness. These dyes could be stored for further use. These dyes do not have a wide range of colors and function only in the slightly warmer temperature $\left(40-48^{\circ} \mathrm{C}\right)$. Cibcron $\mathrm{F}$ dyes are used for dyeing the cellulose fibers as well as the silk and wool.

\subsubsection{Sabracon F.}

These dyes' functioning is similar to the Procion MX dyes, but these found as little less reactive than the Procion MX. These Sabracon F dyes provide a color range from delicate pastel to vibrant and outstanding wash fastness. Sabracon F is used for dyeing the cellulose fibers as well as the silk and wool.

\subsubsection{Drimarene K.}

These dyes could work under a wide range of temperatures $\left(30-50^{\circ} \mathrm{C}\right)$ and are stable in both powders as well liquid form. These dyes are not considered suitable for synthetic fabrics but suitable for dyeing the cellulose fibers, silk, and the printing and dye bath. These dyes give as easy wash fastness. These dyes remain active and can be stored for future use.

\subsubsection{Remazol.}

Most commonly used for silk printing and also the cellulose fibers and wool. These are found as less reactive than the other dyes. These are more stable in water as these dyes have the masking group, which stops them from reacting with the water.

\subsubsection{Direct dyes.}

These dyes are the cheapest among all other dyes. These dyes are having an absence of fixing property and drying up quickly. These dyes work within the temperature range of 79.4- 
$93.3^{0} \mathrm{C}$. Direct dyes are used for dyeing the cellulose fibers, rayon, silk, and wool and the use of chemical fixative agents.

\subsubsection{Naphthol.}

These dyes are prepared by mixing the two different chemicals - naphthol and the diazo salts, which determine the color of the dye. This dye is considered as the cold-water dye and used within the ice water only. Naphthol is supposed to contain the more harmful chemicals, making them less suitable for use at home.

\subsubsection{Vat dyes.}

Applied on cellulose fibers and also cotton. These dyes give fastness of washing, bleaching, and light. These dyes are reported as the indigo dyes' derivatives and provide other vat dyes such as indigoid, thioindigoid, anthraquinone, etc. [54].

\subsubsection{Sulfur dyes.}

These dyes display good light fastness, low-cost and excellent washing fastens. Apart from all this, the utilization of Sulphur dyes always remains high [54].

\begin{tabular}{|l|l|l|}
\hline Procion MX & $\begin{array}{c}\text { Reactive } \\
\text { dyes }\end{array}$ & Cibcron F \\
\hline Sabracron F & Drimarene F & Remazol \\
\hline Direct dyes & Indigo & Naphtol \\
\hline
\end{tabular}

Figure 3. Types of dyes used for cellulose fibers.

\subsection{Dyes for the protein fibers.}

Protein fibers are obtained from animals and are more complex than cellulose fibers. The dyes are having high $\mathrm{pH}$ denature the protein fibers. Therefore, acid dyes are preferred for dyeing the protein fibers such as wool, angora, cashmere, and silk. The most important acid dyes used for the protein Fibers are -azo dyes, triarylmethane, and anthraquinone.

\subsubsection{Azo dyes.}

These dyes provide high color intensity and brightness to the fibers. Azo dyes are used for about 60-70 percent of all the dye groups. Azo dyes are highly water-soluble and belong to the largest group of synthetic aromatic dyes [55].

\subsubsection{Triarylmethane dyes.}

These dyes are broadly used in stamp inks, printing, and writing.

\subsubsection{Anthraquinone dyes.}

Suitable for dyeing wool and silk. A sub-class of these dyes is used for dyeing the protein fibers, i.e., fiber reactive dyes. 


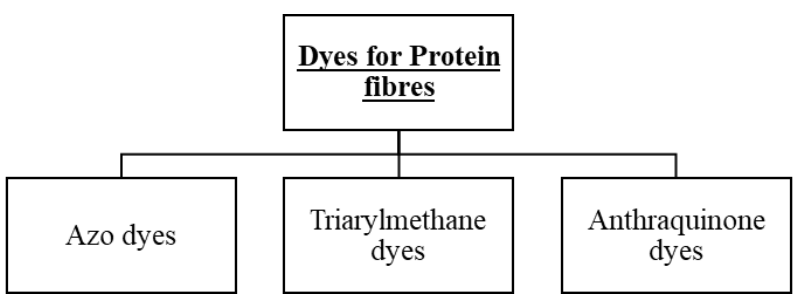

Figure 4. Types of dyes used for the dyeing of protein fibers.

\subsection{Dyes for the synthetic fibers.}

Dispersed dyes are the mainly used dyes for synthetic fibers, which are mostly applied for the printing of nylon, polyesters, acetates, etc. Depending upon their energy, the dispersed dyes are categorized into the following - a. E type - is low energy used in thermosol dying; $b$. $\mathrm{S}$ type - high energy and used in high pressure/high-temperature dyeing; c. SE type - suitable for all types of dyeing methods.

\subsubsection{Direct dyes.}

They are used to dye synthetic fibers and protein fibers. These dyes don't get dried fast after being applied to the fabric.

\subsubsection{Basic dyes.}

Found as the cationic dyes as these dyes form cationic salt after getting dissolved in the water. These are considered effective and powerful dyes for acrylic fibers [56].

\subsubsection{Disperse dyes.}

These are the synthetic colorants that are commonly applied in the textile industry. These dyes are applied to the polyesters but also applied for nylon, cellulose acetate, acrylic fibers, etc. [54].

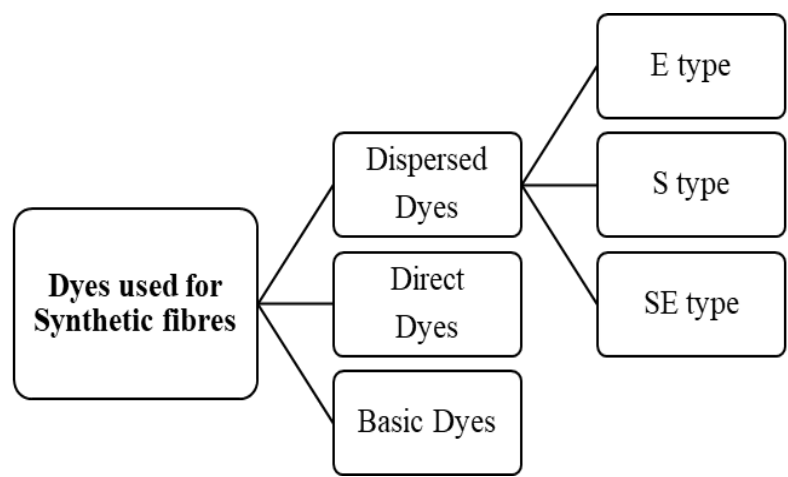

Figure 5. Types of dyes used for synthetic fibers.

\section{Methods of Treatment of Effluents from the Textile Industry}

The effluents released from the textile industries consist of a mixture of dyes, metals, and pollutants. The effluents discharged have a $\mathrm{pH}$, color, suspended solid particles, COD and BOD, etc. [53]. There are physical, chemical, and biological methods for the treatment of effluents from the textile industry. The treatment of effluents with one of these three methods is not enough in decolorizing and the other effluents from the wastewater. While some dyes are not easy to biodegrade as some of the acidic dyes don't easily get absorbed, so they skip 
the treatment. Therefore, there is a need to combine different effluent treatment methods because such a combination can remove $85 \%$ of the non-desired matter [57].

\begin{tabular}{|l|}
\hline Physical methods \\
\hline - Adsorption \\
- Coagulation and \\
flocculation \\
- Membrane process \\
- Ultra filtration \\
- Micellar enhanced \\
Ultrafiltration \\
- Reverse osmosis \\
- Nanofiltration \\
\end{tabular}

\begin{tabular}{|l|}
\hline Chemical methods \\
\hline - Photocatalytic \\
degradation of dyes \\
- Oxidation and \\
photocatalysis with \\
hydrogen peroxide \\
$\left(\mathrm{H}_{2} \mathrm{O}_{2}\right)$ \\
- Ozonation \\
- Degradation of dyes \\
using sodium \\
hypochlorite $(\mathrm{NaOCl})$ \\
- Electrochemical \\
method
\end{tabular}

\section{Biological methods}

- Bioremediation / Biodegradation

- Stabilization

- Aerated lagoons

- Trickling filters

- Activated sludge

- Anaerobic digestion

- Fungal treatment

- Flocculation

Figure 6. Representation of the methods of treatment of effluents from the textile industry.

Various treatment methods of effluents from the textile industries have been explained below [58].

\subsection{Physical methods.}

The help of logically occurring forces such as gravity, electrical attraction, van der Waal forces, etc., can exclude substances in effluent management. As these forces don't alter the chemical structure of the required molecules. Therefore, the physical methods include the following methods -

\subsubsection{Adsorption.}

This method is considered the most efficient method for the management of effluents or industrial wastewater. In this method, natural and synthetic adsorbents are used, e.g., silica, alumina, ferrierite, etc., while the activated carbon is found as the most effective adsorbent for removing organic compounds from the industrial effluents. Apart from this, polymeric adsorbents that occur in nature and cellulose bio-adsorbents produced synthetically are also used.

\subsubsection{Coagulation and flocculation.}

In this method of effluents treatment, organic and inorganic coagulants are used. Organic coagulants such as polymers and inorganic coagulants, including alum, lime, and iron salts, are used. Among these, alum is considered the most significant and efficient inorganic salt for separating dyes from the textile's effluents. When the coagulation binds up with the filtration, then the process is most commonly preferred for removing heavy metals, organic carbon, iron, manganese, etc. 


\subsubsection{Membrane process.}

This method has the capability to reuse the material, i.e., used for the dyeing, and helps in the separation of the dyestuff. The advantage o this method is that it helps in the separation of dyes, elucidation, and concentration. This method is not widely used or preferred as this requires special equipment, highly expensive, and membrane-fouling, etc.

\subsubsection{Ultrafiltration.}

This method allows the revival of the dyes from water. It removes the particles and macromolecules from wastewater. The transport properties of the membrane are based on the thickness of the membrane. This method is preferred as pre-treatment for reverse osmosis.

\subsubsection{Micellar enhanced ultrafiltration (MEUF).}

This is the best technique recognized for the removal of impurities. Most industries have used the ultra-filtration technique, but this MEUF demands further filtration and no direct reuse. This method is used to remove both dyes as well as multivalent metal ions from the water.

\subsubsection{Reverse osmosis.}

This method is found as hyper-filtration, where water moves through the partially permeable membrane.

\subsubsection{Nanofiltration.}

The effectiveness of this method lies between ultrafiltration and reverse osmosis. By using this approach, reactive dyes can be effectively separated from the wastewater.

\subsection{Chemical methods.}

Using these methods, the chemical oxidation of the pollutants present in the textile effluents leads to the removal of the toxicity in them. Oxidizing agents are chosen for chemical oxidation. The different types of chemical methods are described below.

\subsubsection{Photocatalytic degradation of dyes.}

This approach is most commonly used in the modern era. In the presence of some nanoparticles and oxidants, the dyes undergo degradation immediately. Such degradation of the dyes depends upon the photocatalytic properties of them. Various catalysts such as $\mathrm{TiO}_{2}$, $\mathrm{ZnO}$, nanoparticles are also used to remove the color of the variety of synthetic dyes.

\subsubsection{Oxidation and photocatalysis with hydrogen peroxide $\left(\mathrm{H}_{2} \mathrm{O}_{2}\right)-$}

This method preferred for handling the textile effluents in two kinds of systems, as given below.

a. Homogenous system - by using the UV or visible light, ozone, peroxidase etc.

b. Heterogeneous system - by using semiconductors light, zeolites, clays etc.

$\mathrm{H}_{2} \mathrm{O}_{2}$ removes the color from the industrial wastewater due to the presence of $\mathrm{Fe}$ (II) sulfate and titanium oxide. 


\subsubsection{Ozonation.}

It is applied for the removal of colors from synthetic dyes. The major limitation of this method is that it releases hazardous molecules and carcinogenic nitrogenous aromatics. Therefore, this method is not preferred for use.

\subsubsection{Degradation of dyes using sodium hypochlorite $(\mathrm{NaOCl})$.}

$\mathrm{NaOCl}$ is preferred as a cleaning agent and disinfectant. The benefit associated with it is that it can be easily stored and transported. The dyes which contain the amino acids in their groups are degraded by treating with this chemical. The major drawback of using $\mathrm{NaOCl}$ is that it releases poisonous chlorine gas after mixing with the acids. So precautions should be appropriately followed $[59,60]$.

\subsubsection{Electrochemical method.}

This method is based on the redox reaction, which separates the metals from the wastewater. This technique has become trendy in the last two decades. The electrochemical method further involves electrocoagulation techniques, electro-disinfection, electro- floatation, electro-deposition, electro-oxidation, etc. this technique is beneficial in the different types of industrial effluents. It is a flexible and generous skill. In this approach, the electron is the key reagent that acts as a disinfectant and does not produce solid remains [57].

\subsection{Biological method.}

This bioremediation method becomes more preferred over the physical and chemical methods as this approach is cost-effective and eco-friendly. [61] Bioremediation is considered the most powerful approach for treating industrial textile effluents or industrial wastewater loaded with organic components. Around seventy percent of the organic stuff is degraded by applying the biodegradation method. For the synthetic dyes, the bioremediation approach is easy and optional but also found to be complicated. Most of the microbial types have been assessed to remove color and mineralize various dyes [62].

\section{Agricultural Waste Materials as an Adsorbent}

Between the several conservative techniques for exclusion of dye particles from sewages, the adsorption of contaminants by non-living biomass (materials of biological origin), inactive and biosorption has been powerfully suggested by scientists universally as an effective and reasonable sustainable tech for the exclusion of artificial colorants from manufacturing sewages [63]. The adsorption potential of farming waste matter of sugarcane bagasse used to eradicate malachite green dye from aqueous solution was studied. The adsorbent was measured by FTIR analysis and BET surface arena quantification. Several specifications such as contact time, adsorbent dose, temperature, and initial dye concentration were considered to detect their outcome on the dye adsorption method. At finest principles of the exceeding specification, greater than $95 \%$ exclusion ability was grown within $120 \mathrm{~min}$ at an adsorbent dose of $1 \mathrm{~g} / \mathrm{L}$ for a preliminary dye concentration of $50 \mathrm{mg} / \mathrm{L}$. The adsorption of dye was found to follow a pseudo-second-order rate equation [63]. Farming waste is an environmentally friendly resource, abundant and low cost that is utilized as an extremely effective adsorbent. The most used sources to remove the dye and heavy metals are peat bagasse, coffee powder, pistachio 
peel, squash coal, rice hulls ash, garlic peel, banana peel, pomelo peel, tea waste, coconut shells, orange peel, pomegranate peel, and squash coal. The key elements of agricultural waste include water, hemicelluloses, proteins, lignin, simple sugars, hydrocarbons, starches, and lipids, encompassing several forms of functional groups. These functional groups lead to an increase of active sites and greater adsorption of impurities [64].

\subsection{Natural form of agricultural waste utilized as adsorbent.}

Due to forestry and agricultural industries, by-products are formed. It could be presumed to be cost-effective adsorbents since they are present in large amounts in nature, cheap, need slight proceeding, and are productive resources. These constituents are accessible in huge amounts and may have the potential as absorptive due to their economic and physiochemical characteristic. The wood industry produced sawdust as a by-product in large amounts that is either utilized as packing material and cooking fuel. Sawdust is straightforwardly obtainable in the countryside at a small cost [65]. The sewage water of various manufacturing, like cosmetics, printing, textiles, paper, leather, etc., encompasses many harmful dyes. There are many method procedures and adsorbents, which are obtainable for the dispensation of this sewage water holding dye content. The application of easily accessible cheap and environmentfriendly adsorbents to eliminate harmful dyes from aqueous waste by the adsorption method has been revised. This review paper has given a collected list of safe to handle, easy-to-disposeoff, low cost, and easily available. These adsorbents have been divided into five different classes based on their state of availability: (1) fruit waste, (2) plant waste, (3) bioadsorbents, (4) natural inorganic materials, and (5) waste constituents from industry and agriculture. A few treated adsorbents have shown decent adsorption range for Congo red, basic red, methylene blue, rhodamine $\mathrm{B}$, crystal violet, etc., but this adsorption procedure is highly dependent on $\mathrm{pH}$, and in this treatment, process $\mathrm{pH}$ plays an important role in the $\mathrm{pH}$ of the medium plays a vital role [66]. The elimination of dyes from waste seepage is very ecologically significant because a slight quantity of dye in water can be visible and toxic [67]. These constituents are often resilient to deprivation using biological methods and are not demolished by conventional chemical and physical methods. Aquatic life is affected by dyes, as it prevents sunlight from passing through the water. Dyes may cause toxic to aquatic animals' environment and significant damage to human life $[68,69]$.

\subsection{Granular activated carbon and chemically treated form of agricultural wastes} utilized as adsorbents.

Forestry and Farming forms secondary products may also suggest renewable and an inexpensive supplementary basis of activated carbons. These waste resources have slight or no commercial value and often present a discarding issue. Therefore, there is a demand to valorize these economic by-products. Thus, an adaptation of waste resources into activated carbons would add significant economic value, help decrease the price of waste disposal, and most significantly gives a significantly reasonable alternative to the prevailing profitable activated carbons. Activated carbon was produced from dehydrated public manure sludge, and group method adsorption experimentations were led to study its potential to eradicate complex reactive dye from dyeing unit effluent [70]. Commercially accessible activated carbons are generally extracted from natural resources such as coal, wood, lignite, and coconut shell, but nearly any carbonaceous substances may be used as a predecessor for the production of carbon 
adsorbents [71]. Activated carbon is a regularly used adsorbent in pharmaceutical and chemical industries, sugar refining, wastewater, water treatment, and adsorbent in point-of-use (POU) point-of-entry (POE) home water filtration systems. Rising necessities for purer and extra refined sewage from various procedures propose that, excluding the expansion of new machinery, the need for industrial activated carbon will only rise in the future [72]. Abundant farmed waste and several unused plant parts offer renewable and an inexpensive supplementary source of activated carbon (AC). These leftover resources have slight or no commercial price and frequently pose a serious dumping problem. So, these leftover elements are used in an untreated and treated method for the elimination of dyes. Porter showed that adsorption of AC is a complete treatment and effective for textile wastewater. Production of ACs from various Agro waste to treat wastewater has been conveyed earlier [73].

\section{Textile Dyes: Impact on Environment}

The textile manufacturing industries consider for two-thirds of the whole dyestuff marketplace. Dyes used to deliver into the wastewater are 10-15\% during the dyeing process and source environmental pollution and problems related to health and several compounds used in the textile industry are regarded as major contaminants in the textile industry's wastewater. Globally, environmental issues related to the textile industry are linked with water contamination produced by the straight liberation of unprocessed sewage and liberation of lethal compounds in the aquatic environment. Due to this occurrence of hydrosulphide in the water body and reductions oxygen concentration and block the sunlight to pass through the water body which is harmful to the water ecology Chlorine are bounded to colorants which are carcinogenic in nature Textile industry effluent contain heavy metals which are not decomposable and assemble in primary tissues of the body and may cause signs of sicknesses. Unprocessed or partly used textile sewage can be detrimental to terrestrial and aquatic life by disturbing the natural environment and producing permanent health issues [44]. A significant hazard to the atmosphere is the existence of unprocessed dyes in water bodies because these reactive dyes inhibit the photosynthesis development of hydrophytes by hindering the sunlight from piercing, which further causes the production of poisonous materials [74]. During oxygen-deficient environment conditions, toxic aromatic amines are formed due to unprocessed dye effluent [75]. Several groups of tumors of a distinct body part such as liver, spleen, bladder, and chromosomal deformities in mammalian cells and normal aberrations in model organisms showed their linkage with azo dyes according to some reports [76] diffused contamination produce the salt level in a water body, which makes it unsuitable for irrigation and human utilization. Chromium $(\mathrm{Cr})$ and sulfur trioxide $\left(\mathrm{SO}_{3}\right)$, and chromium $(\mathrm{Cr})$ are poisonous impurities that create a significant hazard to microorganisms and marine life that are beneficial for the refinement of the water rivulets. Abrupt alterations in dissolved oxygen quantity Bacteria degrade debris leftovers of starch, cotton (organic substances), increasing the oxygen demand in water. Used of diverse substances in textile manufacturing causes differences in $\mathrm{pH}$ in the water and affects aquatic life [78]. When textile industry seepage is used for irrigation, then the plants' chlorophyll content decreases and protein, carbohydrates content of plants decreases, and chlorophyll is a direct sign of poisonous properties of textile dye sewages floras [79]. In general, dyes have little toxic effect in aquatic organisms and mammals [27], but products developed by bio deprivation dyes, mainly aromatic amines from the anaerobic reduction of azo dyes, can be dangerous [80,81]. Reactivity of dyes due to their hydrolyzed form and a high degree of reactivity and due to high steadiness of effluents may 
persist in the atmosphere for a longer period ( 50 years). And nowadays, reactive dyes are mainly utilized in the textile industry. Because of their marketable significance, the toxicity and impact of dyes liberated in the habitat have been broadly studied [81-84]. Azo dyes that are made up of the major group of artificial pigments utilized are subsequently the most common artificial dyes released into the habitat $[85,76]$. Azo dyes have been connected to chromosomal aberrations in cultured mammalian cells, splenic sarcomas, bladder cancer, and hepatocarcinoma, producing nuclear anomalies in the experimental animal. The rise of bladder cancer in dye workers, which are mainly due to contact with great quantities of azo dyes, has appeared [83].

\section{Impact Textile Dyes on Aquatic Environment}

Dyes can cause several environmental and health hazards and persist in the atmosphere for a longer period due to high photostability and thermal to oppose biodegradation. The prominent ecological worry with dyes is their reflection and absorption of light penetrating the water. Sunlight absorption declines the photosynthesis of algae and the food chain. Excess quantity of textile dyes in water bodies ceased the reoxygenation capacity of the receiving water and halted the sunlight, thereby upsetting biological activity in aquatic life and the photosynthesis activity of aquatic plants or algae [86]. Dyes have lethal properties due to occurrence for the longer time period in the atmosphere (i.e., half-life time of several years), Gathering of sediments in aquatic life or in fishes, putrefaction of impurities in cancer-causing or mutagenic chemical compounds, and also low aerobic biodegradability. Numerous dyes and their breakdown products are mutagenic, carcinogenic and/or lethal to life. The small quantities of dyes in the water are very observable, deliberately disturbs the condition and transparency of water bodies like lakes, rivers, and others, major to harm the marine ecology. Azo dyes have lethal properties, mainly mutagenic and carcinogenic. They get in the body by ingestion and are metabolized by intestinal microorganisms causing DNA damage [87, 88].

Table 1. Impact of dyes on fish.

\begin{tabular}{|c|c|c|}
\hline Fish Name & Based on & Impact \\
\hline $\begin{array}{l}\text { Gambusia } \\
\text { affinis }\end{array}$ & - & $\begin{array}{l}\text { Reduction in mortality, Cytotoxic effects on RBCs \& reduction in RBC } \\
\text { counts, Changes in shape (poikilocytosis), Variation in their size [89] }\end{array}$ \\
\hline $\begin{array}{l}\text { Mastacembelus } \\
\text { armatus }\end{array}$ & - & $\begin{array}{l}\text { Changes in ionic regulations of the tissues like liver, kidney and muscle, } \\
\text { Decrease in concentration of sodium and chloride ions, Increase in } \\
\text { concentration of potassium, calcium and magnesium ions [90]. }\end{array}$ \\
\hline Teleost fish & - & $\begin{array}{l}\text { Abnormal behavior including erratic skimming, hyperexcitation, rapid } \\
\text { opercular movement and thick mucus covering. Enlargement of primary } \\
\text { gill bar, Detachment of secondary gill bar. Disintegration of intestinal villi, } \\
\text { Infiltration of hemocytes in the lumen [91]. }\end{array}$ \\
\hline $\begin{array}{l}\text { Oreochroomis } \\
\text { mossambicus }\end{array}$ & $\begin{array}{l}\text { Hematological } \\
\text { Parameters }\end{array}$ & Liver hyperemia, Necrosis, \& Degeneration $[92,93]$ \\
\hline $\begin{array}{l}\text { Spiralothelphusa } \\
\text { hydrodroma }\end{array}$ & $\begin{array}{l}\text { Nutritive Value } \\
\text { of Fresh Water }\end{array}$ & Loss of nutritive value of protein, carbohydrate and lipids $[94,95]$ \\
\hline Catla & $\begin{array}{l}\text { Nutritive Value } \\
\text { of Fresh Water }\end{array}$ & Effects on the rate of feeding, absorption and food conversion $[96,97]$ \\
\hline
\end{tabular}

Table 2. Impact of dyes on algae.

\begin{tabular}{l|l}
\multicolumn{1}{c|}{ Algae Name } & \multicolumn{1}{c}{ Impact } \\
\hline Spirulina platensis & $\begin{array}{l}\text { Increasing the concentration of dyes in water resist } \\
\text { the growth and decrease its nutrient level [98] }\end{array}$ \\
\hline Ramazol Red Brilliant & $\begin{array}{l}\text { Affect the chain in an aquatic environment and } \\
\text { consequently causes an ecological imbalance [99, } \\
100]\end{array}$
\end{tabular}




\begin{tabular}{c|l} 
Algae Name & \multicolumn{1}{|c}{ Impact } \\
\hline Scenedesmus quadricauda & $\begin{array}{l}\text { Reduces the growth and biomass production, } \\
\text { Alters the morphological characteristics of the } \\
\text { freshwater [101] }\end{array}$
\end{tabular}

\section{Conclusions}

Dyes are the major industrial pollutants and water contaminants. Synthetic dyes are used every day worldwide to print fabrics, leather coloring, hair complexion, etc. The effluents released from the Textile industry characterized by a high content of pollutants such as organic and inorganic materials, heavy metals, colorants, and a mixture of dyes and a huge amount of dyes consumption release the pollutants and produces environmental pollution through the effluents getting discharged from the textile industries or others. The effluents discharged have a $\mathrm{pH}$, color, suspended solid particles, COD and BOD, etc. If effluent is directly discharged without being treated, it will bring serious harm and impact on the ecological environment. In the aquatic environments, artificial dyes cause rampant health hazards when they counter with some other chemical compounds and form non-biodegradable secondary products. The seepage ejaculated from textile dyeing mills is not only lethal, but it is also rich in the occurrence of mutagenic and teratogenic cancer-causing as well as mutagenic chemical compounds. Therefore, decolorization of dyes is a significant feature of wastewater treatment before release. It is tough to eradicate the dyes from the sewage because dyes are not easily degradable and are usually not eliminated from wastewater by conventional wastewater systems. Biological aerobic wastewater systems are not successful for decolorization of the majority of dyes. Therefore, to accomplish the desired degree of treatment, it is needed to assimilate physical, biological and chemical procedures and use Agriculture waste materials in their natural, granular activated carbon and chemically preserved form of agricultural wastes used as adsorbents. The treatment of effluents with one of these three methods is not enough in decolorizing and the other effluents from the wastewater. While some dyes are not easy to biodegrade as some of the acidic dyes don't easily get absorbed, so they skip the treatment. Therefore, there is a need to combine different effluent treatment methods because such a combination can remove $85 \%$ of the non-desired matter treatment of effluents from the textile industry.

\section{Funding}

This review received no external funding.

\section{Acknowledgments}

The authors sincerely thank the reviewers for providing helpful comments on earlier drafts of the manuscript.

\section{Conflicts of Interest}

The authors declare no conflict of interests.

\section{References}

1. Brown, D.; Hitz, H. R.; Schäfer, L. The assessment of the possible inhibitory effect of dyestuffs on aerobic wastewater bacteria experience with a screening test. Chemosphere 1981, 10, 245-261, https://doi.org/10.1016/0045-6535(81)90025-4. 
2. Gupta, V. K.; Ali, I.; Saini, V. K.; Van Gerven, T.; Van der Bruggen, B.; Vandecasteele, C. Removal of dyes from wastewater using bottom ash. Industrial \& engineering chemistry research 2005, 44, 3655-3664, https://doi.org/10.1021/ie0500220.

3. Wong, Y. C.; Szeto, Y. S.; Cheung, W. H.; McKay, G. Equilibrium studies for acid dye adsorption onto chitosan. Langmuir 2003, 19, 7888-7894, https://doi.org/10.1021/la030064y.

4. $\mathrm{Hu}, \mathrm{T} . \mathrm{L}$. Removal of reactive dyes from aqueous solution by different bacterial genera. Water Science and Technology 1996, 34, 89-95, https://doi.org/10.1016/S0273-1223(96)00701-9.

5. Desa, A. L.; Hairom, N. H. H.; Sidik, D. A. B.; Misdan, N.; Yusof, N.; Ahmad, M. K.; Mohammad, A. W. A comparative study of $\mathrm{ZnO}-\mathrm{PVP}$ and $\mathrm{ZnO}-\mathrm{PEG}$ nanoparticles activity in membrane photocatalytic reactor (MPR) for industrial dye wastewater treatment under different membranes. Journal of Environmental Chemical Engineering 2019, 7, 103143, https://doi.org/10.1016/j.jece.2019.103143.

6. Wang, S.; Boyjoo, Y.; Choueib, A.; Zhu, Z. H. Removal of dyes from aqueous solution using fly ash and red mud. Water research 2005, 39, 129-138, https://doi.org/10.1016/j.watres.2004.09.011.

7. Gürses, A.; Açıkyıldız, M.; Güneş, K.; Gürses, M. S. Colorants in health and environmental aspects. In Dyes and Pigments 2016, 69-83, Springer, Cham.

8. Li, W.; Mu, B.; Yang, Y. Feasibility of industrial-scale treatment of dye wastewater via bio-adsorption technology. Bioresource technology, 2019, 277, 157-170, https://doi.org/10.1016/j.biortech.2019.01.002.

9. Işik, M.; Sponza, D. T. A batch study for assessing the inhibition effect of Direct Yellow 12 in a mixed $\begin{array}{lllll}\text { methanogenic } \quad \text { culture. Process } \quad \text { Biochemistry } & \text { 2005, }\end{array}$ https://doi.org/10.1016/j.procbio.2004.03.011.

10. Kargi, F.; Ozmihc1, S. Biosorption performance of powdered activated sludge for removal of different dyestuffs. Enzyme and Microbial Technology 267 2004, https://doi.org/10.1016/j.enzmictec.2004.05.002.

11. Mittal, A.; Mittal, J.; Kurup, L. Adsorption isotherms, kinetics and column operations for the removal of hazardous dye, Tartrazine from aqueous solutions using waste materials-Bottom Ash and De-Oiled Soya, as adsorbents. Journal of hazardous materials 2006, 136, 567-578, https://doi.org/10.1016/j.jhazmat.2005.12.037.

12. Mittal, A.; Mittal, J.; Kurup, L.; Singh, A. K. Process development for the removal and recovery of hazardous dye erythrosine from wastewater by waste materials - bottom ash and de-oiled soya as adsorbents. Journal of hazardous materials 2006, 138, 95-105, https://doi.org/10.1016/j.jhazmat.2006.05.038.

13. Gupta, V. K.; Mittal, A.; Kurup, L.; Mittal, J. Adsorption of a hazardous dye, erythrosine, over hen feathers. Journal of Colloid and Interface Science 2006, 304, 52-57, https://doi.org/10.1016/j.jcis.2006.08.032.

14. Jain, A. K.; Gupta, V. K.; Bhatnagar, A. Utilization of industrial waste products as adsorbents for the removal of dyes. Journal of hazardous materials 2003, 101, 31-42, https://doi.org/10.1016/S0304-3894(03)00146-8.

15. Gupta, V. K.; Ali, I.; Saini, V. K.; Van Gerven, T.; Van der Bruggen, B.; Vandecasteele, C. Removal of dyes from wastewater using bottom ash. Industrial \& engineering chemistry research 2005, 44, 3655-3664, https://doi.org/10.1021/ie0500220.

16. Gupta, V. K.; Ali, I.; Mohan, D. Equilibrium uptake and sorption dynamics for the removal of a basic dye (basic red) using low-cost adsorbents. Journal of colloid and interface science 2003, 265, 257-264, https://doi.org/10.1016/S0021-9797(03)00467-3.

17. Gupta, V. K.; Suhas,; Ali, I.; Saini, V. K. Removal of rhodamine B, fast green, and methylene blue from wastewater using red mud, an aluminum industry waste. Industrial \& engineering chemistry research 2004, 43, 1740-1747, https://doi.org/10.1021/ie034218g.

18. Kang, J. W.; Hoffmann; M. R. Kinetics and mechanism of the sonolytic destruction of methyl tert-butyl ether by ultrasonic irradiation in the presence of ozone. Environmental science \& technology 1998, 32, 3194-3199, https://doi.org/10.1021/es970874u.

19. Boye, B.; Dieng, M. M.; Brillas, E. Degradation of herbicide 4-chlorophenoxyacetic acid by advanced electrochemical oxidation methods. Environmental Science \& Technology 2002, 36, 3030-3035, https://doi.org/10.1021/es0103391.

20. Gerischer, H. Photoelectrochemical catalysis of the oxidation of organic molecules by oxygen on small semiconductor particles with $\mathrm{TiO} 2$ as an example. Electrochimica acta 1993, 38, 3-9, https://doi.org/10.1016/0013-4686(93)80003-I.

21. Srinivasan, A.; Viraraghavan, T. Decolorization of dye wastewaters by biosorbents: a review. Journal of environmental management 2010, 91, 1915-1929, https://doi.org/10.1016/j.jenvman.2010.05.003. 
22. Khouni, I.; Marrot, B.; Moulin, P.; Amar, R. B. Decolourization of the reconstituted textile effluent by different process treatments: Enzymatic catalysis, coagulation/flocculation and nanofiltration processes. Desalination 2011, 268, 27-37, https://doi.org/10.1016/j.desal.2010.09.046.

23. Saratale, R. G.; Saratale, G. D.; Chang, J. S.; Govindwar, S. P. Bacterial decolorization and degradation of azo dyes: a review. Journal of the Taiwan Institute of Chemical Engineers 2011, 42, 138-157, https://doi.org/10.1016/j.jtice.2010.06.006.

24. Fersi, C.; Dhahbi, M. Treatment of textile plant effluent by ultrafiltration and/or nanofiltration for water reuse. Desalination 2008, 222, 263-271, https://doi.org/10.1016/j.desal.2007.01.171.

25. Fongsatitkul, P.; Elefsiniotis, P.; Yamasmit, A.; Yamasmit, N. Use of sequencing batch reactors and Fenton's reagent to treat a wastewater from a textile industry. Biochemical Engineering Journal 2004, 21, 213-220, https://doi.org/10.1016/j.bej.2004.06.009.

26. Paschoal, F. M. M.; Tremiliosi-Filho, G. Aplicação da tecnologia de eletrofloculação na recuperação do corante índigo blue a partir de efluentes industriais. Química Nova 2005, 28, 766-772, https://doi.org/10.1590/S0100-40422005000500006.

27. O’Neill, C.; Hawkes, F. R.; Hawkes, D. L.; Lourenço, N. D.; Pinheiro, H. M.; Delée, W. Colour in textile effluents-sources, measurement, discharge consents and simulation: a review. Journal of Chemical Technology \& Biotechnology: International Research in Process, Environmental \& Clean Technology 1999, 74, 1009-1018, https://doi.org/10.1002/(SICI)1097-4660(199911)74:11\%3C1009::AIDJCTB153\%3E3.0.CO;2-N.

28. Daneshvar, N.; Khataee, A. R.; Ghadim, A. A.; Rasoulifard, M. H. Decolorization of CI Acid Yellow 23 solution by electrocoagulation process: Investigation of operational parameters and evaluation of specific electrical energy consumption (SEEC). Journal of hazardous materials, 2007 148, 566-572, https://doi.org/10.1016/j.jhazmat.2007.03.028.

29. Kunz, A.; Peralta-Zamora, P.; Moraes, S. G. D.; Durán, N. Novas tendências no tratamento de efluentes têxteis. Química nova 2002, 25, 78-82, http://dx.doi.org/10.1590/S0100-40422002000100014.

30. Verma, A. K.; Dash, R. R.; Bhunia, P. A review on chemical coagulation/flocculation technologies for removal of colour from textile wastewaters. Journal of environmental management 2012, 93, 154-168, https://doi.org/10.1016/j.jenvman.2011.09.012.

31. Singh, B.; Bauddh, K.; Bux, F. Algae and environmental sustainability, Springer, 2015, 7, 97-106.

32. Wong, J. K. H.; Tan, H. K.; Lau, S. Y.; Yap, P. S.; Danquah, M. K. Potential and challenges of enzyme incorporated nanotechnology in dye wastewater treatment: A review. Journal of environmental chemical engineering, 2019, 7, 103261, https://doi.org/10.1016/j.jece.2019.103261.

33. Babu, B. R.; Parande, A.; Raghu, S.; Kumar, T. P. Textile technology. Technology. J. Cotton. Sci., 1995, 11, 141-153.

34. Cui, M. H.; Gao, L.; Lee, H. S.; Wang, A. J. Mixed dye wastewater treatment in a bioelectrochemical system$\begin{array}{lllll}\text { centered } & \text { process. Bioresource } & \text { technology 2020, } & 297, & 122420 \text {, }\end{array}$ https://doi.org/10.1016/j.biortech.2019.122420.

35. Afroze, S.; Sen, T.; Ang, M. Agricultural solid wastes in aqueous phase dye adsorption: a review. Agricultural wastes: Characteristics, types and management 2015, 169-213, http://hdl.handle.net/20.500.11937/20557.

36. Guo, D.; Xiao, Y.; Li, T.; Zhou, Q.; Shen, L.; Li, R.; Lin, H. Fabrication of high-performance composite nanofiltration membranes for dye wastewater treatment: mussel-inspired layer-by-layer selfassembly. Journal of colloid and interface science 2020, 560, 273-283, https://doi.org/10.1016/j.jcis.2019.10.078.

37. Verma, A. K., Dash, R. R., Bhunia, P. A review on chemical coagulation/flocculation technologies for removal of colour from textile wastewaters. Journal of environmental management 2012, 93, 154-168, https://doi.org/10.1016/j.jenvman.2011.09.012.

38. Mittal, A.; Jain, R.; Mittal, J.; Shrivastava, M. Adsorptive removal of hazardous dye quinoline yellow from wastewater using coconut-husk as potential adsorbent. Fresenius Environ. Bull 2010, 19, 1-9.

39. Odjegba, V. J.; Bamgbose, N. M. Toxicity assessment of treated effluents from a textile industry in Lagos, Nigeria. African Journal of Environmental Science and Technology 2012,6, 438-445, https://doi.org/10.5897/AJEST12.133.

40. Gómez, N.; Sierra, M. V.; Cortelezzi, A.; Capítulo, A. R. Effects of discharges from the textile industry on the biotic integrity of benthic assemblages. Ecotoxicology and environmental safety 2008, 69, 472-479, https://doi.org/10.1016/j.ecoenv.2007.03.007. 
41. Khan, S.; Malik, A. Environmental and health effects of textile industry wastewater. In Environmental deterioration and human health 2014, 55-71, Springer, Dordrecht.

42. Selvakumar, K. V.; Basha, C. A.; Prabhu, H. J.; Kalaichelvi, P.; Nelliyan, S. The potential of free cells of Pseudomonas aeruginosa on textile dye degradation. Bioresource technology 2010, 101, 2678-2684, https://doi.org/10.1016/j.biortech.2009.10.077.

43. Mahmood, S.; Arshad, M.; Khalid, A.; Nazli, Z. H.; Mahmood, T. Isolation and screening of azo dye decolorizing bacterial isolates from dye-contaminated textile wastewater. Soil \& Environment 2011, 30.

44. Kant, R. Textile dyeing industry an environmental hazard. Natural Science 2012, 4, 22-26. http://dx.doi.org/10.4236/ns.2012.41004.

45. Georgiou, D.; Aivazidis, A.; Hatiras, J.; Gimouhopoulos, K. Treatment of cotton textile wastewater using lime and ferrous sulfate. Water Research 2003,37, 2248-2250, https://doi.org/10.1016/S00431354(02)00481-5.

46. Merzouk, B.; Madani, K.; Sekki, A. Using electrocoagulation-electroflotation technology to treat synthetic solution and textile wastewater, two case studies. Desalination 2010,250, 573-577, https://doi.org/10.1016/j.desal.2009.09.026.

47. Valley, B.; Jing, B.; Ferreira, M.; Zhu, Y. Rapid and efficient coacervate extraction of cationic industrial dyes from wastewater. ACS applied materials \& interfaces 2019, 11, 7472-7478, https://doi.org/10.1021/acsami.8b21674.

48. Mor, S.; Chhavi, M. K.; Sushil, K. K.; Ravindra, K. Assessment of hydrothermally modified fly ash for the treatment of methylene blue dye in the textile industry wastewater. Environment, development and sustainability 2018, 20, 625-639.

49. Kim, T. H.; Park, C.; Yang, J.; Kim, S. Comparison of disperse and reactive dye removals by chemical coagulation and Fenton oxidation. Journal of hazardous materials 2004,112, 95-103, https://doi.org/10.1016/j.jhazmat.2004.04.008.

50. Madakka, M.; Jayaraju, N.; Rajesh, N.; Chandra, M. R. G. S. Development in the treatment of municipal and industrial wastewater by microorganism. In Recent Developments in Applied Microbiology and Biochemistry 2019, 263-273, Academic Press, https://doi.org/10.1016/B978-0-12-816328-3.00020-9.

51. Kiran, S.; Adeel, S.; Nosheen, S.; Hassan, A.; Usman, M.; Rafique, M. A. Recent trends in textile effluent treatments: A review. Adv. Mater. Wastewater Treat 2017, 29, 29-49, https://doi.org/10.1002/9781119407805

52. Yaseen, D. A.; Scholz, M. Textile dye wastewater characteristics and constituents of synthetic effluents: a critical review. International journal of environmental science and technology 2019, 16, 1193-1226, https://doi.org/10.1007/s13762-018-2130-z.

53. El Harfi, S.; El Harfi, A. Classifications, properties and applications of textile dyes: A review. Applied Journal of Environmental Engineering Science 2017, 3, 0-3, https://doi.org/10.48422/IMIST.PRSM/ajeesv3i3.9681.

54. Sarkar, S.; Banerjee, A.; Halder, U.; Biswas, R.; Bandopadhyay, R. Degradation of synthetic azo dyes of textile industry: a sustainable approach using microbial enzymes. Water Conservation Science and Engineering 2017, 2, 121-131, https://doi.org/10.1007/s41101-017-0031-5.

55. Ghaly, A. E.; Ananthashankar, R.; Alhattab, M. V. V. R.; Ramakrishnan, V. V. Production, characterization and treatment of textile effluents: a critical review.J Chem Eng Process Technol 2014, 5, 1-18, http://dx.doi.org/10.4172/2157-7048.1000182.

56. Ciblak, A.; Mao, X.; Padilla, I.; Vesper, D.; Alshawabkeh, I.; Alshawabkeh, A. N. Electrode effects on temporal changes in electrolyte $\mathrm{pH}$ and redox potential for water treatment. Journal of Environmental Science and Health, Part A, 2012, 47, 718-726.

57. Üstün, G. E.; Solmaz, S. K. A.; Birgül, A. Regeneration of industrial district wastewater using a combination of Fenton process and ion exchange-A case study. Resources, Conservation and Recycling 2007, 52, 425440, https://doi.org/10.1016/j.resconrec.2007.05.006.

58. Rutala, W. A., Weber, D. J. Uses of inorganic hypochlorite (bleach) in health-care facilities. Clinical microbiology reviews 1997, 10, 597-610, https://doi.org/10.1128/CMR.10.4.597.

59. Fukuzaki, S. Mechanisms of actions of sodium hypochlorite in cleaning and disinfection processes. Biocontrol science 2006, 11, 147-157, https://doi.org/10.4265/bio.11.147.

60. Guieysse, B.; Norvill, Z. N. Sequential chemical-biological processes for the treatment of industrial wastewaters: review of recent progresses and critical assessment. Journal of hazardous materials 2014, 267, 142-152, https://doi.org/10.1016/j.jhazmat.2013.12.016. 
61. Mahmoud, M. S. Decolorization of certain reactive dye from aqueous solution using Baker's Yeast $\begin{array}{llll}\text { (Saccharomyces } & \text { cerevisiae) } & \text { strain. HBRC } & \text { journal }\end{array}$ https://doi.org/10.1016/j.hbrcj.2014.07.005.

62. Sharma, N.; Nandi, B. K. Utilization of sugarcane baggase, an agricultural waste to remove malachite green dye from aqueous solutions. J. Mater. Environ. Sci 2013, 4, 1052-1065.

63. Elliott, C.; Colby, T.; Iticks, H. Activated carbon obliterans alter aspiration of activated charcoal. Chest 1989, 96, 672-674, https://doi.org/10.1378/chest.96.3.672.

64. Hameed, B. H.; Ahmad, A. L.; Latiff, K. N. A. Adsorption of basic dye (methylene blue) onto activated carbon prepared from rattan sawdust. Dyes and pigments 2007, 75, 143-149, https://doi.org/10.1016/j.dyepig.2006.05.039.

65. Sharma, P.; Kaur, H.; Sharma, M.; Sahore, V. A review on applicability of naturally available adsorbents for the removal of hazardous dyes from aqueous waste. Environmental monitoring and assessment 2011, 183, 151-195, https://doi.org/10.1007/s10661-011-1914-0.

66. Rangabhashiyam, S.; Anu, N.; Selvaraju, N. Sequestration of dye from textile industry wastewater using agricultural waste products as adsorbents. Journal of Environmental Chemical Engineering 2013, 1, 629-641, https://doi.org/10.1016/j.jece.2013.07.014.

67. Chiou, M. S.; Ho, P. Y.; Li, H. Y. Adsorption of anionic dyes in acid solutions using chemically cross-linked chitosan beads. Dyes and pigments 2004, 60, 69-84, https://doi.org/10.1016/S0143-7208(03)00140-2.

68. Kadirvelu, K.; Kavipriya, M.; Karthika, C.; Radhika, M.; Vennilamani, N.; Pattabhi, S. Utilization of various agricultural wastes for activated carbon preparation and application for the removal of dyes and metal ions from aqueous solutions. Bioresource technology 2003, 87, 129-132, https://doi.org/10.1016/S09608524(02)00201-8.

69. Reddy, S. S.; Kotaiah, B.; Comparative evaluation of commercial and sewage sludge based activated carbons for the removal of textile dyes from aqueous solutions. Journal of Environmental Health Science \& Engineering 2006, 3, 239-246.

70. Nasr, M. F.; Abo El-Ola, S. M.; Ramadan, A.; Hashem, A. A comparative study between the adsorption behavior of activated carbon fiber and modified alginate I. Basic dyes adsorption. Polymer-Plastics Technology and Engineering 2006,45, 335-340, https://doi.org/10.1080/03602550600553176.

71. Amuda, O.; Ibrahim, A. Industrial wastewater treatment using natural material as adsorbent. Afr. J. Biotechnol, 2006, 5(16), 1483-1487, https://doi.org/10.3390/ma14010034.

72. Pollard, S. J. T.; Fowler, G. D.; Sollars, C. J.; Perry, R. Low-cost adsorbents for waste and wastewater treatment: a review. Science of the total environment 1992, 116, 31-52, https://doi.org/10.1016/00489697(92)90363-W.

73. Wang, H.; Su, J. Q.; Zheng, X. W.; Tian, Y.; Xiong, X. J.; Zheng, T. L. Bacterial decolorization and degradation of the reactive dye Reactive Red 180 by Citrobacter sp. CK3. International Biodeterioration \& Biodegradation 2009, 63, 395-399, https://doi.org/10.1016/j.ibiod.2008.11.006.

74. Murugesan, K.; Kalaichelvan, P. T. Synthetic dye decolourization by white rot fungi. Indian J Exp Biol. 2003, 41, 1076-1087.

75. Ali, H. Biodegradation of synthetic dyes-a review. Water, Air, \& Soil Pollution 2010, 213, 251-273. https://doi.org/10.1007/s11270-010-0382-4.

76. Asamudo, N. U.; Daba, A. S.; Ezeronye, O. U; Bioremediation of textile effluent using Phanerochaete chrysosporium. African Journal of Biotechnology 2005, 4.

77. Singh, R.; Gautam, N.; Mishra, A.; Gupta, R. Heavy metals and living systems: An overview. Indian journal of pharmacology 2011, 43, 246, https://dx.doi.org/10.4103\%2F0253-7613.81505.

78. Sweeny, G. Fast fashion is the second dirtiest industry in the world, next to big oil. EcoWatch. 2015. Available online: http://ecowatch.com/2015/08/17/fast-fashion-second-dirtiest-industry/ (accessed on 28th Feb 2021).

79. Razo-Flores, E.; Luijten, M.; Donlon, B. A.; Lettinga, G.; Field, J. A. Complete biodegradation of the azo dye azodisalicylate under anaerobic conditions. Environmental science \& technology 1997, 31, 2098-2103, https://doi.org/10.1021/es960933o.

80. Pinheiro, H. M.; Touraud, E.; Thomas, O. Aromatic amines from azo dye reduction: status review with emphasis on direct UV spectrophotometric detection in textile industry wastewaters. Dyes and pigments 2004,61, 121-139, https://doi.org/10.1016/j.dyepig.2003.10.009.

81. Mathur, N.; Bhatnagar, P.; Bakre, P. Assessing mutagenicity of textile dyes from Pali(Rajasthan) using Ames bioassay. Applied ecology and environmental research 2006, 4, 111-118. 
82. Puvaneswari, N.; Muthukrishnan, J.; Gunasekaran P. Toxicity assessment and microbial degradation of azo dyes. Indian J Exp Biol. 2006, 44, 618-626.

83. Pereira, L.; Coelho, A. V.; Viegas, C. A.; Dos Santos, M. M. C.; Robalo, M. P.; Martins, L. O. Enzymatic biotransformation of the azo dye Sudan Orange $\mathrm{G}$ with bacterial CotA-laccase. Journal of biotechnology 2009, 139, 68-77, https://doi.org/10.1016/j.jbiotec.2008.09.001.

84. Zhao, X.; Hardin, I. R.; HPLC and spectrophotometric analysis of biodegradation of azo dyes by Pleurotus ostreatus. Dyes and Pigments 2007, 73, 322-325, https://doi.org/10.1016/j.dyepig.2005.11.014.

85. Wakkel, M.; Khiari, B.; Zagrouba, F. Textile wastewater treatment by agro-industrial waste: equilibrium modelling, thermodynamics and mass transfer mechanisms of cationic dyes adsorption onto low-cost lignocellulosic adsorbent. Journal of the Taiwan Institute of Chemical Engineers 2019, 96, 439-452.

86. Gita, S.; Hussan, A.; Choudhury, T. G. Impact of textile dyes waste on aquatic environments and its treatment. Environ. Ecol 2017, 35, 2349-2353.

87. Soni, P.; Sharma, S.; Sharma, S.; Kumar, S.; Sharma, K. P. A comparative study on the toxic effects of textile dye wastewaters(untreated and treated) on mortality and RBC of a freshwater fish Gambusia affinis(Baird and Gerard). Journal of environmental biology 2006, 27, 623-628.

88. Kumar, R., Sankhla, M. S., Kumar, R., \& Sonone, S. S. (2021). Impact of Pesticide Toxicity in Aquatic Environment. Biointerface Research in Applied Chemistry, 11(3), 10131-10140., http://dx.doi.org/10.33263/BRIAC113.1013110140.

89. Karthikeyan, S.; Jambulingam, M.; Sivakumar, P.; Shekhar, A. P.; Krithika, J.; Impact of textile effluents on fresh water fish Mastacembelus armatus (Cuv. \& Val). E-journal of Chemistry 2006, 3, 303-306, https://doi.org/10.1155/2006/701612.

90. Selvaraj, D.; Leena, R.; Kamal, D. C. Toxicological and histopathological impacts of textile dyeing industry effluent on a selected teleost fish Poecilia reticulata. Asian Journal of Pharmacology and Toxicology 2015, 3, 26-30.

91. Amte, G. K.; Mhaskar, T. V. Impact of textile-dyeing industry effluent on some haematological parameters of freshwater fish Oreochromis mossambicus. Nature Environment and Pollution Technology 2013, 12, 93.

92. Singh, J.; Sharma, S.; Basu, S. Synthesis of Fe2O3/TiO2 monoliths for the enhanced degradation of industrial dye and pesticide via photo-Fenton catalysis. Journal of Photochemistry and Photobiology A: Chemistry 2019, 376, 32-42. https://doi.org/10.1016/j.jphotochem.2019.03.004.

93. Mohamed, W. A.; Handal, H. T.; Ibrahem, I. A.; Galal, H. R.; Mousa, H. A.; Labib, A. A. Recycling for solar photocatalytic activity of Dianix blue dye and real industrial wastewater treatment process by zinc oxide quantum dots synthesized by solvothermal method. Journal of Hazardous Materials 2021, 404, 123962 , https://doi.org/10.1016/j.jhazmat.2020.123962.

94. Dong, H.; Guo, T.; Zhang, W.; Ying, H.; Wang, P.; Wang, Y.; Chen, Y. Biochemical characterization of a novel azoreductase from Streptomyces sp.: Application in eco-friendly decolorization of azo dye wastewater. International journal of biological macromolecules 2019, 140, 1037-1046. https://doi.org/10.1016/j.ijbiomac.2019.08.196.

95. Sirirerkratana, K.; Kemacheevakul, P.; Chuangchote, S. Color removal from wastewater by photocatalytic process using titanium dioxide-coated glass, ceramic tile, and stainless steel sheets. Journal of Cleaner Production, 2019, 215, 123-130, https://doi.org/10.1016/j.jclepro.2019.01.037.

96. Sankhla, M. S.; Kumari, M.; Sharma, K.; Kushwah, R. S.; Kumar, R. Water contamination through pesticide $\&$ their toxic effect on human health. International Journal for Research in Applied Science and Engineering Technology, 2018, 6, 967-970.

97. Sankhla, M. S.; Kumari, M.; Nandan, M.; Kumar, R.; Agrawal, P. Heavy metals contamination in water and their hazardous effect on human health-a review. Int. J. Curr. Microbiol. App. Sci. 2016, 5, 759-766, https://dx.doi.org/10.2139/ssrn.3428216.

98. de Sousa, M. L.; de Moraes, P. B.; Lopes, P. R. M.; Montagnolli, R. N.; de Angelis, D. D. F.; Bidoia, E. D. Contamination by remazol red brilliant dye and its impact in aquatic photosynthetic microbiota. Environmental Management and Sustainable Development 2012, 1, 129, http://dx.doi.org/10.5296/emsd.v1i2.2512.

99. Chia, M. A.; Musa; R. I. Effect of indigo dye effluent on the growth, biomass production and phenotypic plasticity of Scenedesmus quadricauda (Chlorococcales). Anais da Academia Brasileira de Ciências 2014, 86, 419-428, https://doi.org/10.1590/0001-3765201420130225. 
100.Mohan, H.; Rajput, S. S.; Jadhav, E. B.; Sankhla, M. S.; Sonone, S. S.; Jadhav, S.; Kumar, R. Ecotoxicity, Occurrence, and Removal of Pharmaceuticals and Illicit Drugs from Aquatic Systems. Biointerface Research in Applied Chemistry, 2021, 11, 12530-12546, https://doi.org/10.33263/BRIAC115.1253012546.

101.Sonone, S. S.; Jadhav, S.; Sankhla, M. S.; Kumar, R. Water Contamination by Heavy Metals and their Toxic Effect on Aquaculture and Human Health through Food Chain. Letters in Applied NanoBioScience, 2020, 10, 2148-2166, https://dx.doi.org/10.33263/LIANBS102.21482166. 